\title{
真空・薄膜徒然草 2
}

金原粲*1

\section{Gleanings from My Research on Vacuum and Thin Films 2}

\author{
Akira KINBARA*1 \\ ${ }^{* 1}$ Institute of Industrial Science, The University of Tokyo \\ (Received February 23, 2010, Accepted March 18, 2010)
}

(承前)

\section{5. 真空礼賛+ついでに苦言}

前回「真空」という学術用語に疑問を呈してしまったが, 実生活で真空という言葉をなくせと言うつもりはない. 冷え かかったみそ汁の蓋が開きにくい原因, 我が家で重宝してい るプラスチックの吸盤の貼り付き, 掃除機の吸引, 旧式の弁 を使った井戸用ポンプの汲み上げなどなど，真空のおかげな いしは真空のせいといういい方が相応しく，「低圧」で置き 換えたのでは即物的で有り難みがない. 真空装置を低圧装置 などといわれると，仕事に対する研究意欲が減退する.

全くの私見であるが, もっと重要な真空の応用例は蒸気機 関ではなかったかと思っている，18世紀末，パパン，サヴ アリー，ニューコメンに始まり，19世紀に入ってワットで 完成したといわれる蒸気機関は, 打湯を沸かせて蒸気を作 り，その高圧を利用してピストンを動かす機関であるという ように小学校では習った. しかし機関である以上サイクル運 動が必要で, 一旦外部に延びたピストンは, 今度は元に戻ら なくてはならない. 実際は, 機関の内部の水蒸気を水冷して 凝縮させピストンシリンダー内部を「真空」にし, 大気に仕 事をさせて延びたピストンを戻しているはずである.

この過程がなければ機関として働いたとはいえない. 少し 強引だが，18～19世紀の産業革命の原動力といわれる蒸気 機関は真空の応用機関であり, 水で冷やすだけとはいえ, 真 空技術が産業革命の一翼を担っていたと考えると，真空技術 に関わり合いのある人間の一人として少し嬉しい。

20 世紀以降になると, 真空技術が現代文明に及ぼす役割 は，表だっては目立たないが，裏に回るとますます大きくな ってきている. 我田引水を承知でいえば，真空技術の大きな 役割の一つは, 筆者に関わりの深い薄膜作製技術, さらにそ の延長線上にある集積回路作製技術とそれに続くナノテク用 の材料, デバイス開発技術への適用ではないかと思う. 真 空, 薄膜技術がなければこれらの技術は存在できず, さらに コンピューターも携帯電話もないことになる. 真空, 薄膜技 術は今では IT 革命を下支えしている重要技術の一つなのだ,

そのことと関連するが, 真空研究者の大きな目標の一つ は, 高真空の高速実現のようにみえる。それはそれでよい

*1 東京大学生産技術研究所 ( TEL/FAX 03-5452-6131 e-mail: kinbara@iis.u-tokyo.ac.jp)
が，井戸の汲み上げポンプ, 吸着盤, 蒸気機関などの例から 分かるように, 大気圧の $10^{5} \mathrm{~Pa}$ をほんの少し下回る程度の 真空でも十分に役に立つ場合も多く, $10^{4} \mathrm{~Pa}$ 台の真空の用 途は意外に広いように思える．この領域の技術者は私が知っ ている真空の研究者, 技術者とは人種が違うような気がする が，J. Vac. Soc. Jpn 誌にもときどき彼らを登場させて欲し い.

ここで, つい苦言を呈したくなるのは, 現在の理工系大 学, 高専に拈ける真空技術教育である. 極端な言い方かも知 れないが，今，まともに系統立てて真空技術教育をする場所 は日本真空協会主催の夏季大学くらいではないか. せめて排 気原理, 排気速度, コンダクタンス, 到達圧などの基本概念 くらいは夏季大学に来る前の理工系学部の学生時代に覚え込 ませて颃いて欲しいものだ. 表面物理という名の大学の講義 は見たことがあるが，真空のつく講義をしている教育機関を 私は知らない. 私は, 学部生は表面物理より先に真空科学を 学ぶべきだと思っている. 教育者, 研究者たる大学, 高専教 員は遠慮しすぎて真空教育の重要性をあまり強調していない ように見える. 真空の科学や技術を魅力ある学問に育て上 げ，しっかりした大学・高専のカリキュラムを作って教育に 当たるのは真空関係者の責任である.（注：本稿担当編集委 員より, 山口大学の大学院レベルの特別講座として「実用講 座 真空技術の基礎と応用」が開講されている旨コメントが あった．喜ばしいことではあるが，もう少し多くの大学の学 部レベルでの開講を期待したい.)

\section{6. 薄膜蝗惑 神様と悪魔の狭間}

物質は神様が作ったが，表面は未だ悪魔の手中にあるそう だ。では，悪魔の手の中にある表面の上に作られた薄膜とい う物質は神と悪魔のどちらに属するのだろうか．薄膜に接す ると，原子配列の見事さに思わず「さすが神様！大統領！」 と賛嘆したいこともあるが，物性の不安定さに遭遇すると 「悪魔のこん畜生め!」と怒鳴りたくなることもある．この 神の業と悪魔の仕業の双方が結局薄膜の魅力を作りだしてい るように思える.

筆者が薄膜に関わり合いを持つようになったのは 1950 年 代末に大学院の蓮沼 宏教授の研究室に応用物理の博士課程 学生として入学したてのころである.

蓮沼先生は, 研究テーマについて, とくに細かい指示をな さらず，私の自分勝手を認めて下さった，当時研究室の奈良 
治郎助手（後の宇都宮大学教授）が, 実験用に分光プリズム 表面に銀の薄膜を真空蒸着して鏡を作っていた．脇から見て いた私には，その薄膜が何ともいえず美しく，とくに薄いと きに見せる透過光の色の变化に思わず魅せられて, 修士課程 で行った「熱輻射光の偏光性の研究」は終わりにして, 薄膜 の物性を薄膜固有の性質として研究してみたいと先生に打願 いし, それ以後, 神と悪魔にこづき回されながら一生薄膜と つきあうことになってしまった，それを後海したことはな く, 薄膜の魅力に引き込まれたままである.

蓮沼先生は分光学々光沢研究の大家で, 応用物理全般につ いては大変該博な知識と深い見識を打持ちの先生であった が，薄膜についてはとくに専門家ということではなかった。 というよりも, 当時の日本では薄膜という研究対象が物理や 応用物理の中の独立の分野としては存在していなかったとい う方が多分正しく，その点欧米より遅れていたように思う. もちろん薄膜という物質の形は存在したが, 表面物理の一分 野に扔ける材料として扱わ机，場合により電子回折や光学の 分野で研究者の必要に応じて作製された. 電子回折屋は電子 線が透過するから, 光学屋は干渉が起こるからという理由で 薄膜を作ったが，あくまで原則は薄いバルク物質を作るとい う立場で, 現在のような薄膜固有の構造や性質の研究とは少 しずれがあったと思う。

私は薄膜を応用物理の一分野としてまったくの初歩から勉 強することになったが，指針となる日本語テキストが手近に は見つからず，蓮沼先生から言い渡されたことは，まず

H. Mayer; Physik dünner Schiten I (1950年発行), II (1955年発行)

を読めということで，やむなく丸善に注文して取り寄せた． いず扎も高価で，Iは 5 千円，IIなど 8 千円くらい，今の 值段でいえば10万円くらいした，I は主に光，IIは主に電 子線による薄膜研究の解説で, ドイッ人らしい緻密さと完璧 さで記述されて抢り, 引用文献だけで両方合わせると 1500 以上になる。あえていえば，かなりくどい感じの本である (余談だが Mayer はテキスト中でベクトル記号を使わないの で, 式が長くて読みにくい)。この本で学んだことは, 薄膜 とはただの薄い板ではなくてバルクとは違う別の種類の物体 であるという今は当然と認識されることであった．このこと は, いいかえれば薄膜のサイズ効果に起因するということも できるが，果たして薄膜は神様が好んで作られた物体かどう か，少し手抜きがあるように見えた。その上で実感したの は, 薄膜という特殊で, 当時はあまり実用性が認識されてい なかった物体に関心を持つ研究者が沢山抢り, 薄膜の持つ得 体の知れない悪魔的ないかがわしさが多くの研究者の関心を 引きつけているらしいということであった．この本には随分 お世話になったし，今でもときどき扔世話になるが，外国語 が苦手な筆者にはかなり荷の重い書物ではあった．私が死ん だ後に誰かに譲りたいと思っているのだが, 今の若手で, 果 たしてこの重さに耐えて引き受けてくれる人がいるかどうか 疑わしい。

もうひとつ, 蓮沼先生から, 薄膜作製に役に立つといわれ て購入したのが，やはり名著として知られていたらしい

L. Holland: Vacuum Deposition of Thin Films (1960年発行)
で, Tolansky の推薦文つきである，実験書あるいは技術書 と言われながら真空や薄膜に関するかなり基礎的な記述があ り, 系統的とは言い難いが初心者がまず学ぶべき基本を知る には Mayerの本よりバリアーが低い分むしろ適当だと思っ た．この本も今でも愛用している．こんなにも技術の進歩の 急激な領域で, 50 年後の今でも参考にしたくなるような本 が書けるというのは，やはり著者の基本に対する理解が深い からであろう。

\section{7. 手始めに電気抵抗}

薄膜の物性の特徵を知るのに一番簡単な手段は, ガラスな ぞ絶縁物基板上の金属薄膜の電気抵抗測定で, 学部学生など 初心者に薄膜の特性の一端を実感させるのには手頃である.

比抵抗や電気伝導度の值をきちんと決めるとなると膜厚測定 という厄介な測定が加わるが, 一度何らかの方法で時間と膜 厚の関係を導いておけげ，後は蒸着時間測定でこと足りるこ とも多い。ただし，ただの抵抗測定だと甘く見てはいけな い. とくに薄膜形成の初期過程に扔ける薄い領域での電気抵 抗值の膜厚による变化は劇的で, $\mathrm{M} \Omega$ の桁しか測れない簡便 型のテスターなどで変化を追うことはできない，これは当然 で, 多くの薄膜では形成の初期には薄膜は孤立した金属粒子 あるいは島の集合で, 実際に測定される電気抵抗は, 薄膜中 の金属部分の抵抗ではなく, 島と島の間の絶縁物基板の表面 抵抗であり， $10^{10} \Omega / \square(\mathrm{ohm} / \mathrm{sq}$.) あるいはそれ以上の值に なるからである.この話は後で述べることにして, 以下では 薄膜が一応板とみなせる状態になったときの測定の話をして みよう。

私が抵抗測定をやってみようと思い立ったのは, 先に述べ た Mayerのテキストの電気伝導に関する記述を読んでから である。それに, 測定器もあまりないところで手を付けるに は, 電気抵抗測定が手頃で手っ取り早かった. Mayerのテ キストには薄膜の電気伝導に関わった多数の研究者の研究成 果があげられているが，集大成は Sondheimer が Adv. Phys. 1 (1952) 1 に発表した解説論文によってなされたといってよ い, Advances in Physics 誌はヨーロッパ物理学会が同じ Taylor \& Francis 社から出している原著論文誌 Philosophical Magazine の解説論文誌のようなもので, その発刊の巻 頭論文が Sondheimerによる“The mean free path of electrons in metals”であった. ちなみに, 続く論文が F. Seitz による転位論に関する解説論文, その次が F. C. Frankによ る結晶成長に関する解説論文で, この雑誌の著者には鋝々た るメンバーがそろっていた．ただし Mayerのテキストの出 版と彼の解説論文発表の時間差が少ないせいか, Mayerの テキスト本体の中では彼は余り高く評価されていない，現 在, この理論はあまり顧みられなくなったが，これはこの理 論を必要とする実験環境が少なくなって来たためであろう.

Sondheimerの論文には, かなり煩雑な計算式が出てくる が, 要するに薄膜内部の自由電子の移動を Boltzmann の輸 送方程式を用い, 拡散から電子の流れを説明する理論で, 拡 散現象の中に電場による電子のドリフトを取り入れてあり, 線形近似による簡単化が行われている. 特徵的なのは, 境界 条件として, 薄膜表面における電子の散乱を部分的な非弾性 
散乱効果として取り入れてあることである. 当時はこれこそ が薄膜を薄膜たらしめているサイズ効果の根源のように思え た.この効果は膜が薄いほど相対的に大きくなる．そのため 物性值であるはずの比抵抗あるいは電気伝導度が膜厚に依存 するという結論になる. 非弾性散乱を表面における鏡面反射 係数 $p$ で代表させ, 通常のバルク物質の自由電子による電気 伝導を特徵づける電子密度, 移動度などに加えると $p$ は薄膜 の電気伝導固有のパラメーターになる. 薄膜の電気伝導度を $\sigma$, 比抵抗を $\rho$ で表すと

$$
\begin{aligned}
& \sigma / \sigma_{\infty}=\rho_{\infty} / \rho \\
& =1-[3(1-p) / 2) \kappa_{\infty} \times \\
& \quad \int_{\kappa}^{\infty}\left[\left(1 / s^{3}\right)-\left(\kappa_{\infty}^{2} / s^{5}\right)\left(1-\mathrm{e}^{-s}\right) /\left(1-p \mathrm{e}^{-s}\right)\right] \mathrm{d} s \\
& \kappa_{\infty}=d / L_{\infty} d: \text { 膜厚 } L_{\infty}: \text { 電子の平均自由行程 }
\end{aligned}
$$

（添字。は膜厚ののときの值，すなわちバルク值を示す） という発表当時はかなり有名になった式になる。積分の計算 は解析的にはできないので, 当時, 輸入されたばかりの IBM の大型計算機を扱っていた企業の友人に計算して貪 い, いくつかのpに対して $\rho / \rho_{\infty} v s \kappa_{\infty}$ 曲線を描いて貪っ た.さらにはアメリカ人の友人に頼をれて結果を「輸出」し たりもした，ただ，多くの場合は $d \gg L_{\infty}$ と見なせる範囲で 近似的に

$$
\sigma / \sigma_{\infty} \fallingdotseq 1-3 L_{\infty}(1-p) / 8 d, \rho / \rho_{\infty} \fallingdotseq 1+3 L_{\infty}(1-p) / 8 d
$$

ですませてしまうことが多い.とにかく Fig. 2 に示すよう な実験結果を上の近似式にあわせると, $p$ という表面の電気 的性質を表す量が求まって, 表面の存在を実感できた. デー タのばらつきから，pの測定精度は上がらなかったが，p～ 0 ，つまり表面での電子は完全に非弾性散乱するとしておお むね比抵抗の膜厚変化を説明できた，面白かったのは， $d \rightarrow$ $\infty （$ 実際は $d \sim 0.5 \mu \mathrm{m})$ にしたときの $\rho_{\infty}$ が表に載っている バルク值に一致せず, ものによっては数倍の值になることで あった．薄膜をどうアニールしてもバルク值にならず, 薄膜 はサイズ効果を起こすだけでなく, バルク物質とは違う物質 という考えが抵抗測定を通して私の頭の中に定着した.

ついでであるが, Sondheimer は薄膜に磁場が印加された 場合の薄膜の磁気抵抗効果についても計算を行っている. と いっても GMR (Giant Magneto-Resistance), TMR (Tunnel Magneto-Resistance）に関係する訳ではない。非強磁性金 属の自由電子が磁場により回転運動を起こし, そのために薄 膜表面に衝突する頻度が増えることを考慮した結果の計算で

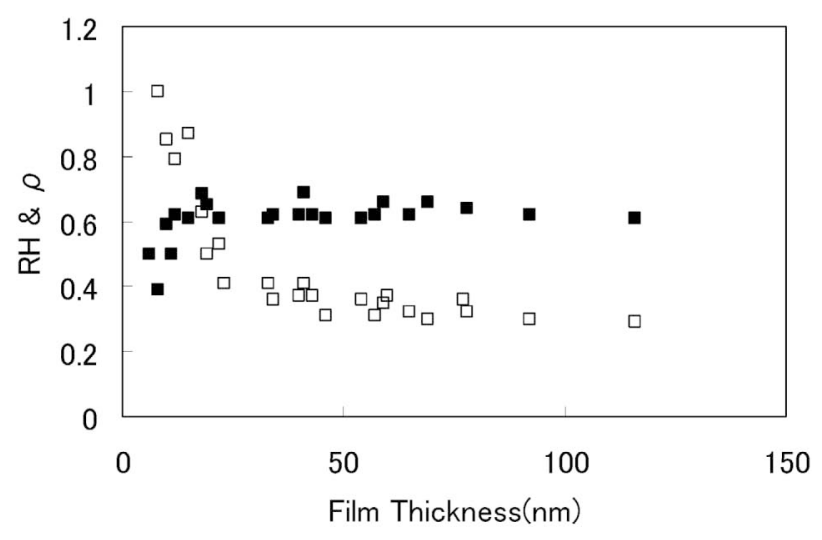

Fig. $2 \mathrm{Cu}$ 薄膜のホール係数 $R_{H}$ の絶対値 $\left[-10^{-10} \mathrm{~m}^{3} / \mathrm{C}\right]$ と比抵抗 $\rho\left[10^{-7} \Omega \mathrm{m}\right]$ の膜厚 $d$ による変化. 実線はバルク 值. 膜厚ののときの $\rho$ はバルク值 $\rho_{\infty}$ と一致しない.

ある.これは薄膜固有の磁気抵抗効果を表しているわけであ るが, 残念ながら我々の持つ装置では磁場の強さが足りずそ の効果を観測することはできなかった.

薄膜では電流密度を上げることが容易であるので, 1970 年当時日立中研から出向してきていた植木和義さんと一緒に $\mathrm{Cu}$ 薄膜のホール効果測定を行ってみた. ホール起電力は電 子（キャリア）密度に反比例する．したがって一般に金属の ホール起電力は半導体に比べて非常に小さいので測定しにく く, 測定例も少ない. そこで, 植木さんが薄い銅板にエッチ ングで長さ $10 \mathrm{~mm}$, 幅数 $\mathrm{mm}$ の試料に極細の電極を 6 本付 けられるマスクを作ってくれた。 それで抵抗/ホール起電力 測定用の $\mathrm{Cu}$ の薄膜試料を真空蒸着で形成できた．これを用 い電流密度を上げると, $3 \mathrm{kG}$ 程度の磁場で $\mu \mathrm{V}$ の桁のホー ル起電力が発生し, 研究室の電位差計で測定できた.この測 定でFig. 2 に示したようにホール係数の絶対值はバルク值 より 10〜 20\%位大きく, 膜厚が減少すると減る, という結 果が出てしまった.この傾向はインド工科大学の Chopra 教 授らの結果と反対だと彼らからクレームがきたが，膜厚が小 さくなると島状ないしは不連続構造の影響が出るので, ホー ル係数測定の意味自体に問題が起こると思っている. 当時は 研究室に組成や構造を調べる機器が無く, それらと実験結果 を関連づけることができなかった。（つづく） 